\title{
Colour Doppler ultrasound hemodynamic characteristics of patients with priapism before and after therapeutic interventions
}

\author{
Rei K. Chiou, MD, PhD; Himanshu Aggarwal, MD; Christopher R. Chiou, BS; Fleur Broughton, BS; Susan Liu, MD
}

See related article on page 312

\section{Abstract}

Background: Information in the literature on the hemodynamic characteristics of priapism, especially after therapeutic intervention, is very limited. We analyzed our colour Doppler ultrasound (CDU) studies performed for patients with various durations of priapism before and after therapeutic intervention.

Methods: We reviewed 52 CDU studies for 24 patients with priapism before and after treatment for the period 1997-2007. The duration of priapism ranged from 4 hours to 8 days. We performed 17 CDU studies in 8 patients who presented with a duration of priapism of 7 hours or less, 9 studies in 4 patients who presented with duration of priapism of more than 20 hours, 23 studies in 11 patients referred to us after they had failed prior therapeutic intervention at other institutions and 3 studies in 1 patient with priapism related to perineal trauma.

Results: Among the 8 patients who presented with a duration of priapism of 7 hours or less, CDU studies on presentation showed detectible cavernosal arterial flow in all except 1 study. Among the 4 patients who presented with a duration of more than 20 hours, the studies showed no detectible cavernosal arterial blood flow. We repeated CDU studies after therapeutic intervention, and they showed restoration of cavernosal arterial flow with relief of venoocclusive status. Among the 11 patients in whom prior treatments failed before they were referred to us, CDU studies performed on presentation showed no detectible cavernosal arterial flow in 10 of the 11 patients. We performed 12 CDU studies in 8 patients after placing a penile cavernosa-dorsal vein (CD) shunt. We observed the presence of blood flow in the CD shunt, indicating its patency in all 8 patients. Some patients showed high cavernosal arterial flow (peak systolic velocity [PSV] up to $27.6 \mathrm{~cm} / \mathrm{s}$ ) after surgery. These patients appeared to have residual priapism of primarily arteriogenic status that improved after observation.

Conclusion: After therapeutic intervention, CDU study is useful to assess the relief of arteriogenic and veno-occlusive status and the decision for further treatment.

Can Urol Assoc J 2009;3(4):304-11

\section{Résumé}

Contexte : La littérature offre très peu de renseignements sur les caractéristiques hémodynamiques du priapisme, en particulier après une intervention thérapeutique. Nous avons analysé les données provenant d'examens par échographie Doppler en couleurs (ÉDC) menés avant et après une intervention thérapeutique chez des patients atteints de priapisme de durée variable.

Méthodes : Nous avons passé en revue les données de 52 examens par échographie Doppler en couleurs effectués avant et après le traitement de 24 patients atteints de priapisme entre 1997 et 2007. La durée du priapisme variait entre 4 heures et 8 jours. Dix-sept ÉDC ont été effectuées chez 8 patients ayant présenté un priapisme d'une durée maximale de 7 heures; 9 ÉDC ont été effectuées chez 4 patients ayant présenté un priapisme d'une durée de plus de 20 heures. Finalement, 23 ÉDC ont été effectuées chez 11 patients qui nous avaient été dirigés en raison de l'échec de l'intervention thérapeutique antérieure dans d'autres établissements. Trois ÉDC ont été menées chez un patient atteint d'un priapisme relié à un traumatisme périnéal.

Résultats : Chez les 8 patients dont le priapisme avait eu une durée maximale de 7 heures, les ÉDC ont montré au départ un débit sanguin perceptible dans l'artère caverneuse dans tous les cas sauf un. Sur les 4 patients dont le priapisme avait duré plus de 20 heures, les examens par ÉDC n'ont montré aucun débit sanguin dans l'artère caverneuse au départ. Les ÉDC ont été répétées après l'intervention thérapeutique et ont permis d'observer un retour du débit sanguin dans l'artère caverneuse avec soulagement de l'occlusion veineuse. Chez les 11 patients qui n'avaient pas répondu aux traitements antérieurs avant de nous consulter, les ÉDC effectuées au départ n'ont montré aucun débit sanguin perceptible dans l'artère caverneuse dans 10 cas. Nous avons effectué 12 ÉDC chez 8 patients après une dérivation veineuse dorso-caverneuse et avons observé la présence d'un débit sanguin dans la dérivation, montrant sa perméabilité chez les 8 patients. Chez certains patients, on a noté un débit sanguin élevé dans l'artère caverneuse (vitesse systolique maximale de $27,6 \mathrm{~cm} / \mathrm{sec}$ ) après la chirurgie. Ces patients semblaient présenter un priapisme résiduel artériogène primaire qui s'est résorbé par la suite. Conclusion : Après une intervention thérapeutique, les examens par ÉDC permettent d'évaluer le soulagement des troubles artériogènes et/ou veino-occlusifs et d'orienter le traitement subséquent.

\section{Introduction}

The literature on the hemodynamic characteristics of priapism after therapeutic intervention is very limited. Penile 
colour Doppler ultrasound (CDU) has been reported to be a useful method for differentiating nonischemic (high-flow) from ischemic (low-flow) priapism. ${ }^{1,2}$ However, the diagnostic criteria for high-flow versus low-flow priapism are poorly defined. Furthermore, the use of CDU hemodynamic study after therapeutic intervention in patients with priapism has not been previously reported. Many patients with priapism require subsequent intervention after initial treatment. ${ }^{3}$ The decision for second surgery is often made based solely on the clinical persistence of priapism. Penile hemodynamic characteristics are important not only for the initial assessment of priapism, but also for treatment decisions after the initial intervention. The main objective of our study was to assess the importance of CDU at various stages of priapism and its role in postoperative patients. We sought to analyze the CDU studies performed for patients with priapism at various stages of management to gain insight into the hemodynamics of priapism and improve our treatment decisions for priapism.

\section{Methods}

We reviewed $52 \mathrm{CDU}$ studies in 24 patients with priapism before and after treatment for the period 1997-2007. The duration of priapism ranged from 4 hours to 8 days. We performed 17 CDU studies in 8 patients who presented with a duration of priapism of 7 hours or less without prior therapeutic intervention and 9 studies in 4 patients who presented with a duration of priapism of more than 20 hours without prior therapeutic intervention. We did not have patients presenting with 7-20 hours' duration in this series. We performed $23 \mathrm{CDU}$ studies in 11 patients who were referred to us after prior therapeutic intervention had failed. We performed $3 \mathrm{CDU}$ studies in 1 patient with arteriogenic priapism related to perineal trauma.

\section{Main outcome measure}

An experienced urologist (R.K.C.) performed most of the studies in a urology office using either ATL HDI or Acuson ASPEN ultrasound units. With the penis gently placed toward the abdomen and the transducer placed at the ventral surface of penis, we examined the cavernosal arterial blood flow of the proximal and midpenile shafts and measured hemodynamic parameters, including peak systolic velocity (PSV), end diastolic velocity (EDV) and resistive index (RI). We used the proximal penile shaft hemaodynamic parameters as the representative data for interpretation and data analysis. In the patient with perineal trauma, we also placed the transducer at the perineum to examine the cavernosal arteries at the crura.

\section{Results}

The ages of the 24 patients included in our study ranged from 15 to 70 years. The causes of priapism were idiopathic $(n=9)$, penile injection for erectile dysfunction $(n=9)$, use of trazodone $(n=2)$, chronic renal failure $(n=1)$, perineal trauma $(n=1)$, leukemia $(n=1)$ and sickle cell disease $(n=1)$. Among the 11 patients who were referred to us after prior therapeutic intervention had failed, 2 patients had aspiration and intracavernous pharmacotherapy and 9 patients had shunt surgeries at other institutions: 8 patients had cavernoso-glandular shunts, 6 had Winter shunts, 2 had AlGhorab shunts and 1 patient had both cavernoso-glandular and cavernoso-spongiosal (Quackels) shunts. The longest duration of follow-up was 7 years in 1 patient, but CDU was not necessary at subsequent follow-ups; the longest duration of follow-up after which subsequent CDU was required was 1.5 years.

Among the 8 patients who presented with a duration of priapism of 7 hours or less without any prior therapeutic intervention, the priapism was caused by penile injection therapy for erectile dysfunction (ED) in 7 patients. The remaining patient had repeated episodes of priapism of idiopathic etiology. All but 1 of the CDU studies performed at the time of presentation showed the presence of cavernosal arterial flow with varied PSV and EDV (Table 1). These findings indicate a mixed arteriogenic and veno-occlusive hemodynamic status of priapism. After therapeutic intervention with penile aspiration and intracavernous pharmacotherapy, most patients who had high cavernosal arterial flow before treatment showed a decrease in PSV after treatment, indicating improvement in the arteriogenic component of priapism. Most patients with negative EDV values before therapy had increased EDV values after therapy, indicating improvement in veno-occlusive component of priapism (Table 1). In 1 patient with an idiopathic cause of priapism, we performed $4 \mathrm{CDU}$ studies at the time of presentation at separate episodes of priapism of 4, 5, 6 and 7 hours' duration, respectively. The hemodynamic characteristics varied. In one episode of priapism of 7 hours' duration, CDU study showed a high PSV $(34.1 \mathrm{~cm} / \mathrm{s})$ with a positive EDV (4.15), indicating primarily an arteriogenic status of priapism. In another 2 episodes with 4 and 6 hours' duration, CDU studies showed high PSVs $(24.1 \mathrm{~cm} / \mathrm{s}$ and $25.2 \mathrm{~cm} / \mathrm{s})$ with negative EDVs $(-6.3$ and $-3.9 \mathrm{~cm} / \mathrm{s})$, respectively, indicating a mixed arteriogenic and veno-occlusive status of priapism. In another episode of 5 hours' duration, CDU study showed no detectible cavernosal arterial flow, indicating primarily veno-occlusive status of priapism. We performed $6 \mathrm{CDU}$ studies after penile aspiration and intracavernous pharmacotherapy in this group of 8 patients. After treatment for 
Chiou et al.

mixed arteriogenic and veno-occlusive hemodynamic status, CDU studies showed a decrease of PSV, indicating improvement in the arteriogenic component, and an increase of $E D V$, indicating improvement in the veno-occlusive status of priapism. The CDU study performed after treatment in the patient who had an episode of priapism with venoocclusive ischemic status showed a restoration of cavernosal arterial blood flow and a 0 or positive value of EDV, indicating relief of the veno-occlusive status of priapism. Physical examination also showed the resolution of priapism in these patients after the therapeutic intervention (Table 1).

Among the 4 patients who presented with a duration of priapism of more than 20 hours without prior therapeutic intervention, CDU studies performed at the time of presentation showed no detectible cavernosal arterial blood flow, indicating primarily a veno-occlusive status of priapism. We repeated $5 \mathrm{CDU}$ studies in 3 patients after therapeutic intervention, which showed restoration of cavernosal arterial flow with 0 or positive EDV values indicating the relief of veno-occlusive status (Table 2).

In 10 of the 11 patients who were referred to us afrter prior treatments had failed, CDU studies performed at the time of presentation showed no detectible cavernosal arterial flow at the proximal penile shaft, indicating a primarily

\begin{tabular}{|c|c|c|c|c|c|c|c|c|c|c|c|}
\hline \multirow[b]{2}{*}{ Patient } & \multirow[b]{2}{*}{ Age, yr } & \multirow[b]{2}{*}{ Cause } & \multirow[b]{2}{*}{ Duration, $\mathrm{h}$} & \multirow[b]{2}{*}{$\begin{array}{l}\text { Previous } \\
\text { treatment }\end{array}$} & \multicolumn{3}{|c|}{ CDU before treatment } & \multirow[b]{2}{*}{ Treatment } & \multicolumn{3}{|c|}{ CDU after treatment* } \\
\hline & & & & & $\begin{array}{l}\text { PSV } \\
\mathrm{cm} / \mathrm{s}\end{array}$ & $\begin{array}{l}\mathrm{EDV} \\
\mathrm{cm} / \mathrm{s}\end{array}$ & $\mathrm{RI}$ & & $\begin{array}{l}\mathrm{PSV} \\
\mathrm{cm} / \mathrm{s}\end{array}$ & $\begin{array}{l}\text { EDV } \\
\mathrm{cm} / \mathrm{s}\end{array}$ & $\mathrm{RI}$ \\
\hline 1 & 21 & Inj for ED & 4 & None & 1.51 & 0.00 & 1.00 & Asp \& IPT & 5.22 & 1.10 & 0.79 \\
\hline 2 & 46 & Inj for ED & 4 & None & 23.10 & -4.85 & 1.21 & Asp \& IPT & - & - & - \\
\hline 3 & 35 & Inj for ED & 4 & None & 23.10 & -3.67 & 1.16 & Asp \& IPT & - & - & - \\
\hline 4 & 70 & Inj for ED & 4 & None & 10.60 & -1.79 & 1.17 & Asp \& IPT & - & - & - \\
\hline 5 & 60 & Inj for ED & 4 & None & 8.31 & -2.53 & 1.30 & Asp \& IPT & 3.25 & 0.00 & 1.00 \\
\hline \multirow[t]{4}{*}{6} & 34 & Idiopathic & 4 & None & 24.10 & -6.30 & 1.26 & Asp \& IPT & & & \\
\hline & & & 5 & None & No flow & No flow & & Asp \& IPT & 9.00 & 5.58 & 0.38 \\
\hline & & & 6 & None & 25.20 & 0.00 & 1.00 & Asp \& IPT & 22.60 & 6.20 & 0.73 \\
\hline & & & 7 & None & 34.10 & 4.15 & 0.79 & Asp \& IPT & & & \\
\hline 7 & 59 & Inj for ED & 5 & None & 4.97 & 0.00 & 1.00 & Asp \& IPT & 10.40 & 0.00 & 1.00 \\
\hline 8 & 64 & Inj for ED & 6 & None & 19.30 & -1.90 & 1.10 & Asp \& IPT & 11.70 & 0.00 & 1.00 \\
\hline
\end{tabular}

Table 2. Colour Doppler ultrasound studies before and after therapeutic intervention in 4 patients who presented with priapism of more than 20 hours' duration

\begin{tabular}{|c|c|c|c|c|c|c|c|c|c|c|c|}
\hline \multirow[b]{2}{*}{ Patient } & \multirow[b]{2}{*}{$\begin{array}{l}\text { Age, } \\
\text { yr }\end{array}$} & \multirow[b]{2}{*}{ Cause } & \multirow[b]{2}{*}{ Duration } & \multirow[b]{2}{*}{$\begin{array}{l}\text { Previous } \\
\text { treatment }\end{array}$} & \multicolumn{3}{|c|}{ CDU before treatment } & \multirow[b]{2}{*}{ Treatment } & \multicolumn{3}{|c|}{ CDU after treatment* } \\
\hline & & & & & $\begin{array}{l}\text { PSV } \\
\mathrm{cm} / \mathrm{s}\end{array}$ & $\begin{array}{l}\text { EDV } \\
\mathrm{cm} / \mathrm{s}\end{array}$ & RI & & $\mathrm{PSV} \mathrm{cm} / \mathrm{s}$ & $\begin{array}{l}\text { EDV } \\
\mathrm{cm} / \mathrm{s}\end{array}$ & RI \\
\hline 1 & 41 & Inj for ED & $22 \mathrm{~h}$ & None & No flow & No flow & - & Winter shunt & $\begin{array}{c}8.52(1 \mathrm{~h}) \\
\text { shunt patent }\end{array}$ & 2.88 & 0.70 \\
\hline 2 & 57 & Inj for ED & $24 \mathrm{~h}$ & None & No flow & No flow & - & Asp \& IPT & & & \\
\hline \multirow[t]{2}{*}{3} & 15 & $\begin{array}{l}\text { Sickle cell } \\
\text { disease }\end{array}$ & $3 d$ & None & No flow & No flow & - & CD shunt & $\begin{array}{c}3.57 \text { (11 d) } \\
\text { shunt patent }\end{array}$ & 0.00 & 1.00 \\
\hline & & & & & & & & & $\begin{array}{l}\text { No flow (1.5 yr) } \\
\text { no flow in shunt }\end{array}$ & No flow & - \\
\hline \multirow[t]{2}{*}{4} & 25 & Idiopathic & $8 d$ & Sudafed & No flow & No flow & - & CD shunt & $\begin{array}{c}10.30 \text { (1 d) } \\
\text { shunt patent }\end{array}$ & 2.33 & 0.80 \\
\hline & & & & & & & & & $\begin{array}{c}6.04(9 \mathrm{~d}) \\
\text { shunt patent }\end{array}$ & 3.02 & 0.50 \\
\hline
\end{tabular}


veno-occlusive status of priapism and indicating that the previous therapeutic interventions had not relieved the venoocclusive mechanism. In 1 patient, cavernosal arterial flow was present but appeared to stop at the area proximal to mid penile shaft junction. In this patient, we noted an arterial branch from the proximal corpus cavernosum to the corpus spongiosum. This anatomical variation may be responsible for the maintenance of the blood flow at the proximal penile shaft. ${ }^{4}$ We placed penile cavernosa-dorsal (CD) vein shunts in all 11 patients..$^{5}$ We then performed 12 postoperative

\begin{tabular}{|c|c|c|c|c|c|c|c|c|c|c|c|}
\hline \multirow[b]{2}{*}{ Patient } & \multirow[b]{2}{*}{$\begin{array}{c}\text { Age, } \\
\text { yr }\end{array}$} & \multirow[b]{2}{*}{ Cause } & \multirow[b]{2}{*}{ Duration } & \multirow[b]{2}{*}{$\begin{array}{l}\text { Previous } \\
\text { treatment }\end{array}$} & \multicolumn{3}{|c|}{ CDU before treatment } & \multirow[b]{2}{*}{ Treatment } & \multicolumn{3}{|c|}{ CDU after treatment* } \\
\hline & & & & & $\begin{array}{l}\text { PSV } \\
\mathrm{cm} / \mathrm{s}\end{array}$ & $\begin{array}{l}\mathrm{EDV} \\
\mathrm{cm} / \mathrm{s}\end{array}$ & RI & & $\mathrm{PSV} \mathrm{cm} / \mathrm{s}$ & $\begin{array}{l}\mathrm{EDV} \\
\mathrm{cm} / \mathrm{s}\end{array}$ & $\mathrm{RI}$ \\
\hline 1 & 45 & Idiopathic & $32 \mathrm{~h}$ & $\begin{array}{l}\text { Asp \& IPT } \\
\text { Winter } \\
\text { shunt }\end{array}$ & No flow & No flow & - & CD shunt & $\begin{array}{c}20.10(1 \mathrm{~h}) \\
\text { shunt patent }\end{array}$ & 0.00 & 1.00 \\
\hline \multirow[t]{3}{*}{2} & 45 & Idiopathic & $2 d$ & $\begin{array}{l}\text { Asp \& IPT } \\
\text { Winter } \\
\text { shunt }\end{array}$ & No flow & No flow & - & CD shunt & $\begin{array}{c}8.29(1 \mathrm{~h}) \\
\text { Shunt patent }\end{array}$ & -2.13 & 1.26 \\
\hline & & & & & & & & & $\begin{array}{l}\text { No flow (1 d) } \\
\text { Shunt patent }\end{array}$ & $\begin{array}{l}\text { No } \\
\text { flow }\end{array}$ & $\begin{array}{l}\text { No } \\
\text { flow }\end{array}$ \\
\hline & & & & & & & & & $\begin{array}{l}\text { No flow (3 d) } \\
\text { Shunt patent }\end{array}$ & $\begin{array}{l}\text { No } \\
\text { flow }\end{array}$ & $\begin{array}{l}\text { No } \\
\text { flow }\end{array}$ \\
\hline 3 & 31 & Idiopathic & $2 d$ & Asp \& IPT & No flow & No flow & - & CD shunt & $\begin{array}{c}20.0(2 \mathrm{~d}) \\
\text { Shunt patent }\end{array}$ & 5.00 & 0.70 \\
\hline 4 & 65 & Idiopathic & $3 d$ & Asp \& IPT & No flow & No flow & - & CD shunt & $\begin{array}{c}7.55(10 \mathrm{~d}) \\
\text { Shunt patent }\end{array}$ & 2.61 & 0.65 \\
\hline \multirow[t]{2}{*}{5} & 30 & Idiopathic & $3 d$ & $\begin{array}{l}\text { Asp \& IPT } \\
\text { AlGhorab } \\
\text { shunt }\end{array}$ & No flow & No flow & - & CD shunt & $\begin{array}{l}21.30(2 \mathrm{~d}) \\
\text { Shunt patent }\end{array}$ & 5.32 & 0.75 \\
\hline & & & & & & & & & $\begin{array}{l}7.00 \text { (1 mo) } \\
\text { Shunt patent }\end{array}$ & 0.00 & 1.00 \\
\hline \multirow[t]{2}{*}{6} & 57 & Trazodone & $3 d$ & $\begin{array}{l}\text { Asp \& IPT } \\
\text { Winter } \\
\text { shunt }\end{array}$ & No flow & No flow & - & CD shunt & $\begin{array}{c}3.00(1 \mathrm{~d}) \\
\text { Shunt patent }\end{array}$ & 0.00 & 1.00 \\
\hline & & & & & & & & & $\begin{array}{c}\text { Normal flow } \\
\text { PSV not } \\
\text { measured (3 wk) } \\
\text { Shunt patent }\end{array}$ & - & - \\
\hline 7 & 49 & Idiopathic & $4 d$ & $\begin{array}{l}\text { Asp \& IPT } \\
\text { Winter } \\
\text { shunt }\end{array}$ & 11.0 & -2.0 & 1.2 & CD shunt & $\begin{array}{c}7.00(1 \mathrm{~h}) \\
\text { Shunt patent }\end{array}$ & 1.22 & 0.80 \\
\hline 8 & 36 & $\begin{array}{l}\text { Chronic } \\
\text { myeloid } \\
\text { leukemia }\end{array}$ & $4 d$ & $\begin{array}{l}\text { Asp \& IPT } \\
\text { AIGhorab } \\
\text { shunt }\end{array}$ & No flow & No flow & - & CD shunt & & & \\
\hline 9 & 36 & Idiopathic & $4.5 \mathrm{~d}$ & $\begin{array}{l}\text { Asp \& IPT } \\
\text { Winter \& } \\
\text { Quackle } \\
\text { shunt }\end{array}$ & No flow & No flow & - & CD shunt & $\begin{array}{l}27.30(4 \mathrm{~d}) \\
\text { Shunt patent }\end{array}$ & - & - \\
\hline 10 & 48 & Trazodone & $6 d$ & $\begin{array}{l}\text { Asp \& IPT } \\
\text { Winter } \\
\text { shunt }\end{array}$ & No flow & No flow & - & CD shunt & & & \\
\hline 11 & 25 & $\begin{array}{l}\text { Chronic } \\
\text { renal } \\
\text { failure }\end{array}$ & $1 \mathrm{wk}$ & $\begin{array}{c}\text { Asp \& IPT } \\
\text { Winter } \\
\text { shunt }\end{array}$ & No flow & No flow & - & CD shunt & & & \\
\hline
\end{tabular}


CDU studies in 8 patients. We observed the presence of blood flow in the $C D$ shunt, indicating its patency in all 8 patients; the cavernosal arterial blood flow became detectible in all 8 patients. The cavernosal arterial PSV varied (Table 3). Some patients showed high cavernosal arterial flow (PSV up to $27.6 \mathrm{~cm} / \mathrm{s}$ ) after successful shunt surgery. These patients appeared to have residual priapism of primarily arteriogenic status that improved after observation (Fig. 1 and Fig. 2).

Priapism developed in 1 patient after pelvic trauma. We performed $3 \mathrm{CDU}$ studies in this patient at different occasions, which showed an arteriosinusoidal malformation at the crura with varied PSV $(13.6 \mathrm{~cm} / \mathrm{s}, 30.9 \mathrm{~cm} / \mathrm{s}$ and $23.4 \mathrm{~cm} / \mathrm{s}$, respectively). The EDV also varied at different occasions $(4.03 \mathrm{~cm} / \mathrm{s}, 0 \mathrm{~cm} / \mathrm{s}$, and $-2.98 \mathrm{~cm} / \mathrm{s}$, respectively), which was suggestive of an arteriogenic origin of priapism with some veno-occlusive component at one occasion.

\section{Discussion}

Priapism is traditionally divided into ischemic (low-flow) and nonischemic (high-flow) categories. ${ }^{6,7}$ Colour Doppler ultrasound is commonly used to assess patients with priapism and to differentiate the 2 types of priapism. ${ }^{7.8}$ However, the diagnostic criteria for ischemic versus nonischemic priapism are poorly defined. In general, patients with minimal or absent cavernosal arterial blood flow in CDU are categorized as having ischemic priapism, and the patients with nonischemic priapism tend to have history of perineal trauma and arteriosinusoidal malformation with the presence of substantial arterial blood flow in CDU examination. ${ }^{9}$ It is generally recommended that patients with ischemic priapism require emergent man-

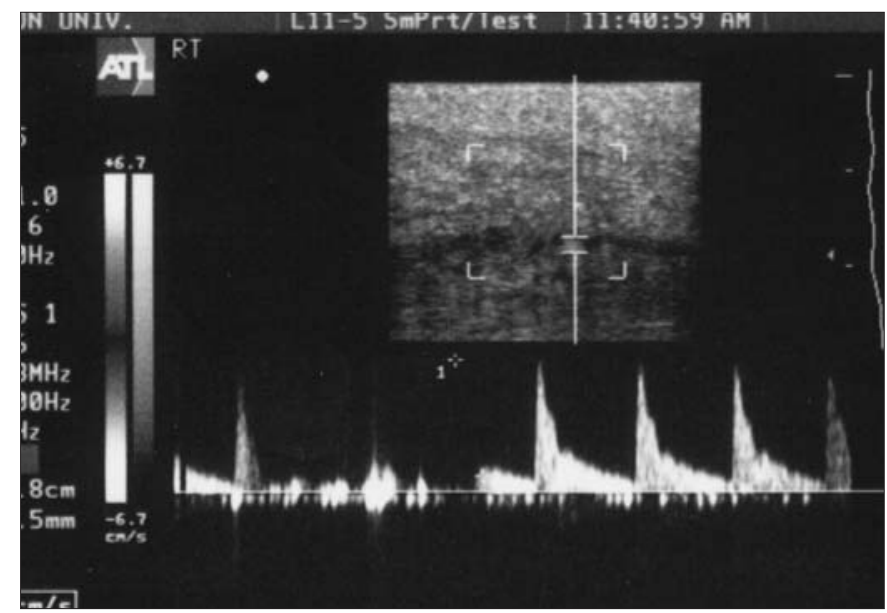

Fig. 1. Colour Doppler ultrasound of a patient with priapism in whom previous treatment with both Winter and Quackles shunts had failed. There was no detectable flow after previous shunt placement, but the patient's condition changed to high-flow after placement of a penile cavernoso-dorsal shunt. agement, whereas patients with nonischemic priapism require observation or elective treatment. One caveat of categorizing patients based on nonischemic and ischemic priapism is our observation that in the course of priapism in an individual patient, the hemodynamic characteristics may vary at different phases of their priapism. Pharmacologically induced erection usually goes through several hemodynamic phases with initially high and subsequently low PSVs. ${ }^{10,11}$ Patients in whom priapism develops after the intracavernosal injection of papaverine or prostaglandin E1 typically have high cavernosal blood flow initially. However, if the priapism remains untreated, it progresses to a low-flow and ischemic status. ${ }^{11}$ Metawea and colleagues ${ }^{11}$ noted that patients with PSV greater than 66 $\mathrm{cm} / \mathrm{s}$ after penile injection therapy had priapism that lasted longer than 6 hours. Shamloul and colleagues ${ }^{12}$ reported that absence of cavernous arterial blood flow after 1 hour of sustained rigid erection predicted priapism. Secil and colleagues ${ }^{13}$ reported that if after intracavernous injection of papaverine patients reach no detectible cavernosal arterial blood flow status, they are likely to have persistent priapism. It is not clear how long the high PSV lasts and at what point the PSV becomes undetectable in patients in whom priapism develops after penile injection therapy. Our data for such patients indicate that when they present with persistent with an erection of 4-7 hours' duration after penile injection therapy for erectile dysfunction, many patients still have a high cavernosal arterial flow. However, it would not be wise to inform patients that they have a high-flow priapism and only require observation. Priapism of other etiologies probably has various phases of hemodynamic events as well. To obtain an erection, a high cavernosal arterial flow is required. In the case of priapism, the point at which the high cavernosal arterial flow becomes

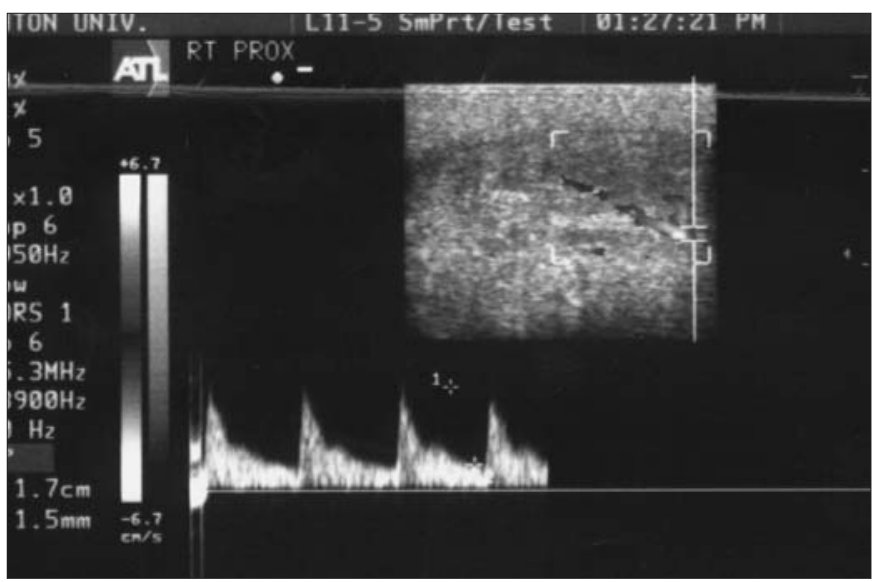

Fig. 2. Colour Doppler ultrasound of a patient with priapism in whom previous treatment with an Al-Ghorab shunt had failed. There was no detectable flow at the proximal penile shaft. After penile cavernoso-dorsal shunt placement, the proximal shaft cavernosal artery had high-flow with a positive end diastolic velocity, indicating the relief of priapism. 
low probably varies among individual patients. In our current series, most patients with a duration of priapism of 7 hours or less still had detectible cavernosal arterial flow, whereas all patients presenting with priapism lasting 20 hours or longer had no detectible cavernosal blood flow on CDU. Further studies are needed to define a cutoff PSV and EDV, which can define at what value the arteriogenic priapism is going to become ischemic, if at all. It is interesting to note that in a patient with recurrent episodes of priapism that were idiopathic in etiology, CDU studies showed varied cavernosal arterial flow in various episodes of almost similar duration. In one episode of 5 hours' duration, he had undetectable flow. In another patient with a 4-hour duration of priapism after penile injection therapy, the PSV was already at a minimal level. Likewise the hemodynamics may change with therapeutic intervention in the same patient. In some patients with low-flow priapism, high cavernosal blood flow status may develop after a successful shunt surgery. Clinically, these patients may appear to have persistent priapism after shunt surgery. We believe that to rigidly categorize patients based on nonischemic or ischemic priapism is inadequate in many clinical situations and it is best to manage priapism with a careful interpretation of CDU hemodynamic findings in conjunction with other clinical assessments.

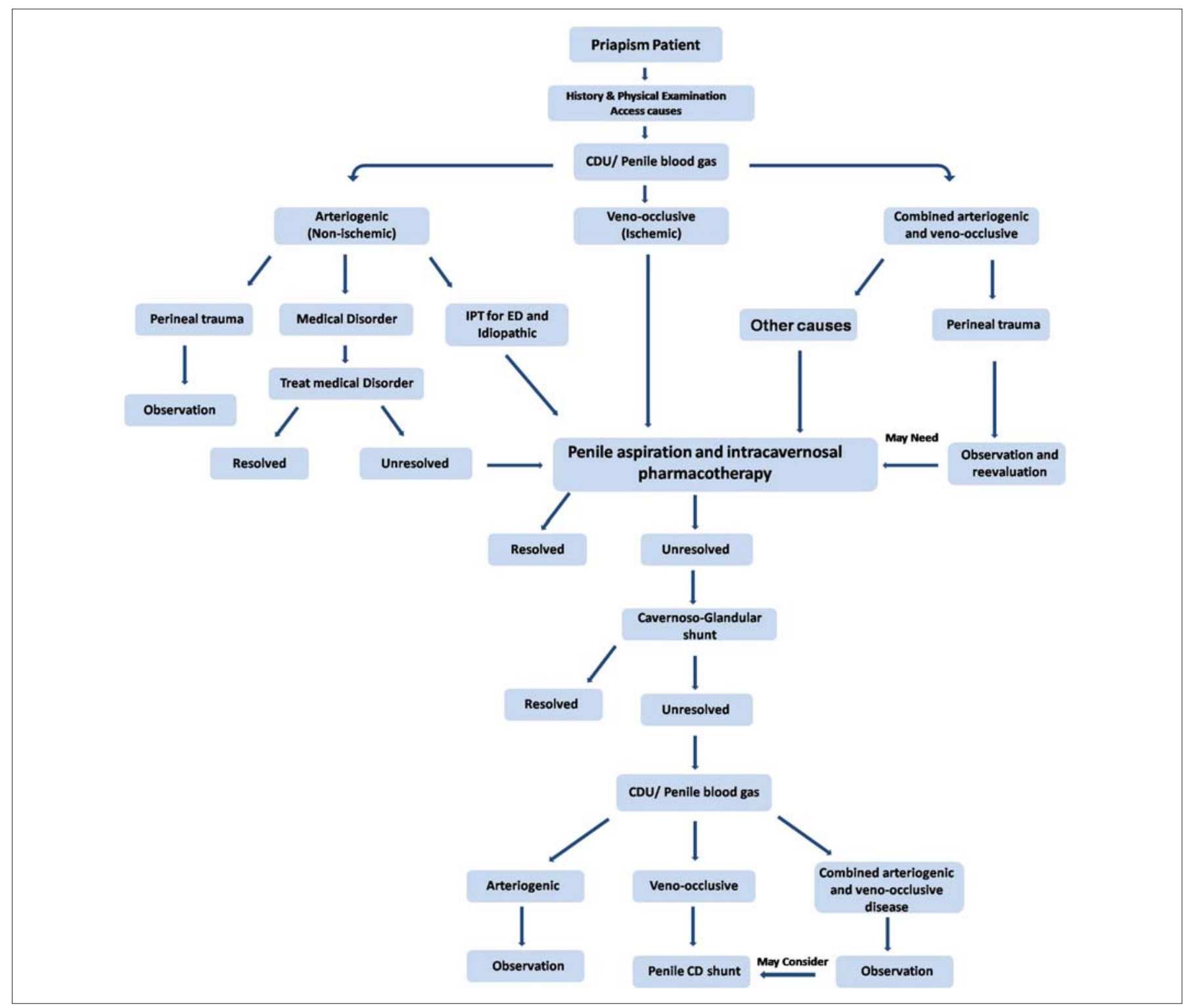

Fig. 3. Current algorithm incorporating colour Doppler ultrasound in the management of patients with priapism. 
We suggest a modification of the traditional classification of nonischemic or ischemic priapism according to the hemodynamic abnormality and underlying pathophysiology as follows:

1. For arteriogenic priapism (priapism of primarily arteriogenic status), CDU studies usually show high PSV with 0 or positive EDV values. Patients typically have perineal trauma that causes cavernosal artery injury. Colour Doppler ultrasound typically shows the presence of arteriosinusoidal malformation. In patients with venoocclusive priapism, arteriogenic priapism may develop after a successful shunt surgery that relieves venoocclusive mechanism effectively.

2. For veno-occlusive priapism (priapism of primarily veno-occlusive status), CDU studies show undetectable or minimal cavernosal arterial flow. When the flow is detectible, the PSV is usually very low and the EDV value is negative. The veno-occlusive mechanism of erection is initially a result of passive compression of pericavernous venules by the dilated sinusoids, which is induced by smooth muscle relaxation and increased cavernosal arterial blood flow. However, we believe that there is thrombosis of emissary veins after a certain period of time of passive compression, which later accounts for persistent veno-occlusive status.

3. For combined arteriogenic and veno-occlusive priapism, CDU studies show the presence of substantial cavernosal arterial flow, as indicated by the high PSV values and the EDV (usually a negative or 0 value). The priapism induced by intracavernosal injection of erectioninducing pharmacological agents typically has both the arteriogenic and the veno-occlusive components during the initial phases. When the effect of pharmacological agents on the cavernosal artery subsides, the persistent priapism may result solely due to the veno-occlusive component.

In the management of priapism, clinical judgment is essential. In addition to considering all other available clinical information for the patient, we believe that understanding the hemodynamic status is of critical importance. Our current algorithm incorporating CDU in the management of priapism is depicted in Figure 3. After the initial therapeutic intervention, the CDU hemodynamic characteristics are important in deciding whether patients should receive further therapy, especially shunt surgery. We believe that CDU study is important in assessing the effectiveness of a shunt procedure. If after surgical shunt placement the CDU study shows veno-occlusive status and the patient still has a persistent erection clinically, it is likely that the shunt procedure is not effective in relieving the veno-occlusive mechanism. These patients would require another form of shunt surgery. Patients who were referred to us after prior treatments had failed typically had veno-occlusive hemodynamic characteristics in CDU studies. We noted a similar finding in a patient who had been treated with a proximal cavernoso-spongiosal shunt in addition to his distal cavernoso-glandular shunt. After we placed penile CD shunts in these patients, we observed a restoration of cavernosal arterial blood flow. However, some patients had a period of high cavernosal blood flow after successful shunt surgery. Such patients may be mistakenly thought to have persistent veno-occlusive priapism and may undergo unnecessary subsequent surgery based solely on physical examination. If patients clinically appeared to have persistent priapism after their initial intervention, we used CDU to assess the patency of the shunt and the cavernosal arterial flow pattern. If the shunt was open and the CDU hemodynamic pattern showed primarily an arteriogenic status, we would observe the patients rather than carrying out further shunt surgery aiming to relieve the veno-occlusive abnormality. These patients typically improved progressively on observation. Thus CDU assessment of the patency of the shunt is very much desirable. The patency of a penile CD shunt can be easily assessed using CDU; the patency of other forms of shunts may be more difficult to evaluate using CDU. We have observed encouraging outcomes among patients with priapism treated with penile CD shunt surgeries. ${ }^{14,15}$ Blood gas has been found to be useful for the assessment of priapism. The correlation of CDU and blood gas requires further study. Other than in patients with priapism related to perineal trauma, we do not routinely examine the perineal crura blood flow. Whether perineal examination of crura blood flow provides additional useful information requires further study. We believe that after a certain period of priapism, various degrees of thrombosis of cavernosal sinusoids, in addition to the thrombosis of emissary vein, may develop inside the corpus cavernosum. We suspect that the thrombosis of cavernosal sinusoids probably starts at the distal penile shaft. At the time of penile aspiration and irrigation, we observed that in some patients the proximal penile shaft became soft but the distal penile shaft remained indurated. This represents the thrombotic changes of the distal cavernosal body. We also observed that after successful shunt surgery some patients had distal penile shaft induration at subsequent follow-ups, which also supports the development of distal cavernosal body fibrosis as a result of thrombosis. The recognition of this phenomenon is clinically important because a cavernoso-glandular shunt (Winter shunt or its modifications) is not likely to work if the distal cavernosal body is thrombosed. 


\section{Conclusion}

Priapism that doesn't resolve after shunt surgery could be explained by 2 reasons: either the shunt is not working or there is increased cavernosal blood flow after surgery, both of which can easily be identified using CDU. If the shunt is not working, no further treatment is warranted if the shunt is patent on $\mathrm{CDU}$, as these patients' conditions tend to improve after some period of observation. Patients in with increased cavernosal blood flow after surgery require some kind of intervention to prevent further damage to erectile tissue.

From the Divisions of Urology, Creighton University Medical Center and University of Nebraska Medical Center; Division of Urology, Department of Veterans Affairs Nebraska Western lowa Healthcare System, Omaha, Nebr.

This article has been peer reviewed.

Competing interests: None declared.

\section{References}

1. Harmon WJ, Nehra A. Priapism: diagnosis and management. Mayo Clin Proc 1997;72:350-5.

2. Goto T, Yagi S, Matsushita S, et al. Diagnosis and treatment of priapism: experience with 5 cases. Urology 1999:53:1019-23.

3. Nixon RG, $0^{\prime}$ Connor IL, Milam DF. Efficacy of shunt surgery for refractory low-flow priapism: a report on the incidence of failed detumescence and erectile dysfunction. J Urol 2003;170:883-6.

4. Chiou RK, Alberts GL, Pomeroy BD, et al. Study of cavernosal artery anatomy using color and power Doppler sonography: impact on hemodynamic parameter measurement. J Urol 1999;162:358-60.

5. Chiou RK, Henslee DL, Anderson JC, et al. Colour Doppler sonography assessment and saphenous vein graft penile veno-corporeal shunt for priaprism. BJU Int 1999;83:138-9.

6. Burnett AL, Bivalacqua TJ. Priapism: current principles and practice. Urol Clin North Am 2007;34: 631-42.

7. Nehra A. Priapism: pathophysiology and nonsurgical management. In: Standard practice in sexual medicine. 2nd ed. Porst H, Buvat J Editors. Malden (MA): Blackwell Publishing; 2007 p. 174-9.

8. Hauri D, Spycher M, Bruhlmann W. Erection and priapism: a new physiopathological concept. Urol Int 1983;38:138-45.

9. Chiou RK, Pomeroy BD, Chen WS, et al. Hemodynamic patterns of pharmacologically induced erection: evaluation by color Doppler sonography. J Urol 1998;159:109-12.

10. Lue TF, Hricak H, Marich KW, et al. Vasculogenic impotence evaluated by high-resolution ultrasonography and pulsed Doppler spectrum analysis. Radiology 1985;155:777-81.

11. Metawea B, El-Nashar AR, Gad-Allah A, et al. Intracavernous papaverine/phentolamine-induced priapism can be accurately predicted with color Doppler ultrasonography. Urology 2005;66:858-60.

12. Shamloul R, Ghanem HM, Salem A, et al. The value of penile duplex in the prediction of intracavernous drug-induced priapism. Int J Impot Res 2004;16:78-9.

13. Secil $M$, Arslan D, Goktay AY, et al. The prediction of papaverine induced priapism by color Doppler sonography. J Urol 2001;165:416-8.

14. Chiou RK, Aggarwarl H, Mues AC, et al. Clinical experience and sexual function outcome of Priapism patients treated with penile cavernosal-dorsal vein shunt using saphenous vein graft. Urology 2009; 73:556-61.

15. Chiou RK, Aggarwal H, Mues AC, et al. Clinical experience and sexual function outcome of priapism patients treated with penile cavernoso-dorsal vein shunt using saphenous vein graft. Urology. In press.

Correspondence: Dr. Rei K. Chiou, Professor and Chief, Division of Urology, Creighton University Medical Center, 601 North 30th St., Suite 3700, Omaha NE 68131; fax 402 280-4309; rchiou@dchealthnet.com

\section{Change of address}

We require 6 to 8 weeks' notice to ensure uninterrupted service. Please send your current mailing label, new address and the effective date of change to:

\section{CUAJ}

1155 University Ave., Suite 1303

Montréal QC H3B 3A7

fax 514 395-1664

journal@cua.org

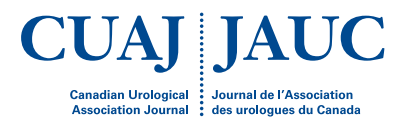

